\title{
Repression, Resistance, and the Law in Post-Coup Thailand
}

\author{
TYRELl HABERKORN
}

$\mathrm{U}$ nder cover of ambiguous pledges of reform, General Prayuth Chan-ocha and his junta, the National Council for Peace and Order (NCPO), have created the most repressive regime in Thailand since a period of military rule inaugurated by an October 1976 massacre and coup. Prayuth's seizure of power, launched on May 22, 2014, was the twelfth successful coup since the end of the absolute monarchy in 1932. The 2007 constitution (the country's eighteenth) was abrogated overnight, martial law put in place, and the jurisdiction of the military courts extended to civilians for crimes against the crown and state. Now, more than a year after the coup, martial law has been revoked but there is no clear sign of either a new constitution or an election.

One way to understand the string of twelve coups, and seven attempted coups, is as an unceasing effort by Thai elites-whether royalist, military, capitalist, or a combination of all threeto regain power. The pattern is similar: With each coup, elites take control of the country until society will no longer bear dictatorship; then citizens rise up to realize the promise of the end of absolute monarchy, namely that all citizens must live under the same law. Yet even though citizens have succeeded in forcing transitions to more democratic regimes, the full implementation of this promise has been deferred because the military passes an amnesty forgiving itself following each coup. The latest coup was no different. The final clause of the July 2014 interim constitution grants Prayuth and members of the NCPO immunity for the coup and any related actions.

What is striking about the new regime is that both the junta's chosen forms of repression and the opposition to its rule are centered on the meaning and exercise of the law. This does not mean that

TYRELL HABERKORN is a fellow in political and social change at Australian National University. there has been a complete absence of extrajudicial violence under the junta, but rather that much of the repression has involved the prosecution of those who dare speak out. To this end, the regime has relied on imaginative interpretations of the existing criminal code. In turn, opponents of the coup have resorted to the judicial system as the frame for their dissent, seeking to protect the individual human rights of those targeted for repression as well as to expose the illegitimacy of the junta. That the junta and the opposition meet and struggle on the field of law-the set of rules governing relations between the rulers and the ruled, or between the state and the citizens-indicates the importance of this moment for the future of the Thai polity.

Both the military and the civilian opposition have broken the deadlock of the long struggles between the royalist-nationalist "yellow shirts" who called for the ouster of Prime Minister Thaksin Shinawatra and the populist-nationalist "red shirts" who demanded a return to electoral democracy after the 2006 coup that ousted him. Although both sides claimed to be fighting for democracy, the color-coded clashes between the 2006 and 2014 coups (the latter removed Thaksin's sister, Prime Minister Yingluck Shinawatra, from office) were largely about who should hold power and the rules for obtaining it. Now the struggle has come much closer to home for all. Citizens are fighting to express their ideas and participate in politics, while the junta is pursuing a legal strategy to close down the political space for public participation and dissent.

\section{CLIMATE OF FEAR}

During the first year after the coup, Prayuth and the NCPO relied on martial law to prohibit public demonstrations, restrict media freedom, shut down academic and other public meetings, make arbitrary arrests, and detain anyone they deemed an enemy for up to seven days. According 
to the Internet Dialogue on Law Reform (iLaw), a Thai nongovernmental organization, at least 772 people were summoned by the junta authorities and detained between the coup and the end of June 2015. There were at least 475 arrests, including 219 at peaceful protests. University students were arrested for holding protests at which they ate sandwiches and read George Orwell's novel 1984, which was first translated into Thai in 1982 but has been reprinted many times-most recently a few months after the coup, when its dystopian vision took on new relevance. Seminars on topics ranging from domestic human rights to the situation in Israel and Palestine to dictatorships overseas were canceled beforehand by order of the authorities or halted by the arrival of uniformed, armed officers in the classrooms.

Martial law was finally revoked by the junta on April 1, 2015, but it was replaced by the extensive use of Article 44, a clause in the 2014 interim constitution that permits the head of the junta to take any action he deems necessary for the preservation of the county.

During prior regimes from the 1950 s to the 1970s, similar measures were used to authorize executions as well as extensive detention powers. Thus far, Article 44 has not been used for summary execution, but instead to ban public demonstrations and authorize arbitrary, incommunicado detention. It has also been used to facilitate the transfer and appointment of civil servants without due process.

While many of those summoned or arrested for protesting were released without charge, 143 people were charged in the military courts and 46 in the civilian courts for political crimes. The differences in adjudication between the military and civilian courts are still emerging, but already an increased preference on the part of the former to hear cases in secrecy and mete out harsher punishments in certain kinds of cases is clear. Most of those targeted by the junta for dissenting are being prosecuted under the Criminal Code Articles 112, for alleged lèse majesté, and 116, for alleged sedition. Neither measure is new, but both have been used in innovative ways to target individual dissidents and create a climate of fear following the May 2014 coup.

Article 112, revived after the September 2006 coup, stipulates: "Whoever defames, insults or threatens the king, queen, heir-apparent, or regent shall be punished with imprisonment of three to fifteen years." The first case was the prosecution of Daranee Charnchoengsilpakul in 2009 for 55 minutes of alleged anti-monarchy speech, for which she was convicted and initially sentenced to 18 years in prison. Her sentence was reduced on appeal to 15 years. Other cases included that of Amphon Tangnoppakul, who was sentenced to 20 years in prison in 2011 for allegedly sending four anti-monarchy text messages. He died in custody in 2012.

Following the 2014 coup, the use of these judicial measures accelerated. There are at least 51 new cases pending in the criminal and military courts, including such crimes as writing graffiti in bathrooms, penning poems, and sharing posts on social media with content deemed to constitute lèse majesté. In effect, Article 112 makes any discussion of the monarchy fraught with peril, particularly any querying of its role in politics. The frail health of 87-year-old King Bhumibol Adulyadej, the world's longest-reigning monarch, and uncertainty over the transition that will follow his death only heighten the fervor of authorities and royalists to use Article 112.

In February 2015, Patiwat Saraiyaem, a finearts student, and Pornthip Munkhong, a recent political science graduate, were sentenced to two and a half years in prison for performing a satirical play, The Wolf Bride, in October 2013 as part of the 40th-anniversary commemorations of the 1973 democracy movement. While the play angered some royalists at the time, the then-democratic government would not countenance the arrest of two young people for a mere dramatic performance. But in the months following the 2014 coup, they were arrested and prosecuted. Bail and not-guilty verdicts are extremely rare in Article 112 cases, so many defendants opt to plead guilty, which ensures that their punishment is halved and makes them eligible for pardon.

According to iLaw, while there were only four known cases of prosecution under Article 116 between 2010 and the coup, there have been at least ten cases involving 25 people since the coup. In several cases, defendants were accused of distributing leaflets criticizing the 
coup. Another case centers on four members of an opposition group, Resistant Citizen, who organized a walk against the coup. Fourteen members of New Democracy, a student and citizen group that emerged on the 83rd anniversary of the transition from absolute to constitutional monarchy, were accused of violating Article 116 by proclaiming their opposition to the junta and announcing a five-point platform of democracy, human rights, justice, public participation, and nonviolence at the Democracy Monument in Bangkok on June 25, 2015.

Article 116 was rarely used before the May 2014 coup, in contrast to Article 112. Upon conviction for sedition, the punishment is up to seven years of imprisonment per count. Most of those accused of violating Article 116 are granted bail; to date, there have been no decisions in any of the cases. Such charges, however, serve as a means of controlling dissidents, who could be prosecuted at any time, and intimidating other citizens who may contemplate joining protests.

\section{FIGHTING BACK}

The junta's active use of the law has necessitated that the opposition also focus on the law and the judicial process. This includes the daily work of those who have responded directly to the junta's rights violations. Thai Lawyers for Human Rights, a coalition of attorneys and activists who came together immediately following the coup, provides legal assistance to citizens affected by the constriction of civil and political rights. Staff and volunteers from iLaw and journalists from the online newspaper Prachatai observe court cases, acting as a visible reminder to judges and other authorities that people are concerned about fairness in the judicial process and determined to witness any deviations.

On the first anniversary of the coup, members of Resistant Citizen filed a 20-page criminal complaint against General Prayuth and members of the junta for overthrowing the elected government. They specified the numerous ways in which the coup itself, and the rights abuses that followed in its wake, are in violation of existing Thai law-the very law that the junta claims to uphold and aims to strengthen. One week later, the Criminal Court dismissed the complaint, ruling that although the coup was not democratic, the amnesty clause in the interim constitution means that Prayuth and the members of the junta cannot be held liable for their actions.

Resistant Citizen, and perhaps even the judges in the Criminal Court, realize that leaving such amnesties unchallenged is dangerous-not only due to the rights violations they permit in the present moment, but because they have a history. Each time a military regime forgives itself for seizing power, detaining people, and criminalizing dissent in the name of national security, it makes the next coup easier because these actions become institutionalized.

Those who oppose the latest coup are not only reacting against dictatorship-they are using the law and the judicial process to expose injustice and display a democratic alternative. Ultimately, their efforts might lead to a different Thailand, where the generals who launched the May 2014 coup could be prosecuted for seizing power, while citizens would be free to walk where they please, distribute flyers, and perform in plays. 